\title{
Population size, sex-ratio and
} sexual dimorphism in Fuchsia parviflora (Onagraceae) an
endemic dioecious shrub

\section{creative} commons

Botanical Sciences

95 (3): 401-408, 2017

DOI: 10.17129/botsci.904

Copyright: (C) 2017 Cuevas et al. This is an open access article distributed under the terms of the Creative Commons Attribution License, which permits unrestricted use, distribution, and reproduction in any medium, provided the original author and source are credited.

\section{Author Contributions}

Eduardo Cuevas conceived and designed the study, wrote the paper. Maria Angeles Pérez performed the study.

Lucero Sevillano analyzed the data, reviewed drafts of the paper.

\section{Universidad Michoacana} de San Nicolás de Hidalgo, Facultad de Biología, Morelia, Michoacán, México

* Corresponding author: eduardocuevas5@gmail.com

\section{Eduardo Cuevas*, María Ángeles Pérez and Lucero Sevillano}

\section{Abstract}

Background: In small dioecious populations stochastic events may increase biased sex ratios decreasing the viability of populations. Moreover, pollinators may promote pollen limitation if sexual dimorphism related to pollinator attraction, such as flower size and number of flowers are present.

Questions: 1) In order to estimate the viability of natural populations of Fuchsia parvifora, population size, sex ratio and fruit production were estimated in natural populations. In addition, number of flowers and floral traits were compared between genders as a way to predict pollinator preferences to particular gender.

Studied species: Fuchsia parviflora is an endemic Mexican dioecious, animal-pollinated shrub.

Methods: In 2012 and 2013 population sizes and sex ratios were estimated in 12 populations in the states of Michoacan and Jalisco. In addition, the number of flowers and floral traits were estimated between genders.

Results: Population sizes varied widely from 14 to 550 individuals and an overall significant male- bias was found Male frequency varied from 50 to $78 \%$ among populations and some male-biased populations were also the small populations. A significant negative correlation between population size and male frequency was found, but no relationship was found between population size and number of flowers or fruit production. Reproductive plant height varied among populations but not between genders within populations. Male plants had larger number of flowers but floral longevity did not differ between genders. Consistently in all evaluated populations, staminate flowers had longer floral tubes and wider corolla diameter than pistillate flowers.

Conclusions: In accordance to stochastic sex ratio fluctuations by small population sizes, it was expected to find populations with male and female-biased sex ratios. However, the absence of female-biased sex ratio suggests that male plants may have a higher survival chance but this hypothesis has to be tested. Although populations seem not to be seed-limited, some populations were cut during this study to plant avocado trees, suggesting the need to implement conservation efforts to preserve populations of $F$. parviflora.

Keywords: biotic pollination, dioecy, floral dimorphism, population size.

\section{Resumen}

Antecedentes: En poblaciones dioicas pequeñas, eventos estocásticos pueden incrementar los sesgos en las proporciones sexuales lo que puede afectar la viabilidad de las poblaciones. Además, los polinizadores pueden promover la limitación de polen si existe un fuerte dimorfismo sexual en el tamaño y número de flores.

Preguntas: Con la finalidad de estimar la viabilidad de las poblaciones de Fuchsia parviflora se estimaron los tamaños poblacionales, las proporciones sexuales y la producción de frutos en poblaciones naturales. Además, se comparó el despliegue floral y los caracteres florales entre géneros como una forma de predecir posibles sesgos de los polinizadores hacia algún género en particular.

Especie de estudio: Fuchsia parviflora es un arbusto dioico de polinización biótica, endémico de México.

Métodos: Durante 2012 y 2013 se estimaron las proporciones sexuales y los tamaños poblacionales en 12 poblaciones del estado de Michoacán y Jalisco. Además, se comparó el despliegue floral y los caracteres florales entre géneros.

Resultados: Las poblaciones variaron entre 14 y 550 individuos y se encontró un ligero sesgo significativo hacia machos en general. La frecuencia de machos entre poblaciones varió entre 50 y $78 \%$ y algunos sesgos a machos se dieron en poblaciones pequeñas. Se encontró una correlación negativa, entre tamaño de la población y frecuencia de machos, pero no entre tamaño de población y despliegue floral o el tamaño poblacional y producción de frutos. La altura de plantas reproductivas varió entre poblaciones, pero no entre sexos dentro de poblaciones. Las plantas masculinas presentaron un despliegue floral mayor, pero la longevidad de flores no difirió entre sexos. En todas las poblaciones evaluadas, las flores masculinas fueron más grandes que las femeninas.

Conclusiones: De acuerdo a las variaciones estocásticas en las proporciones sexuales en poblaciones pequeñas, se esperaba encontrar sesgos hacia machos y hembras. La ausencia de sesgos a hembras sugiere que los machos pueden tener una mayor probabilidad de supervivencia, pero esta hipótesis tiene que ser probada. Aunque las poblaciones no parecen estar limitadas en la producción de frutos, algunas poblaciones fueron cortadas durante el desarrollo de este estudio para plantar árboles de aguacate, lo que sugiere la necesidad de proponer esfuerzos de conservación para preservar las poblaciones de F. parviflora.

Palabras clave: polinización biótica, dioecia, dimorfismo floral, tamaño de población. 
ngiosperms may have the largest diversity of reproductive systems in nature (Barrett 2010). Even though the great majority of plants are hermaphrodites, dioecious species (plants with only staminate or pistillate flowers) are well represented along angiosperm families (Helibuth 2000). An obvious limitation of populations of unisexual plants is the dependence for reproduction on a pollen vector either biotic or abiotic, making these species particularly sensitive to global changes such as habitat fragmentation. Mexico is a mega diverse country with more than 22,000 species of flowering plants (González-Medrano 2003). Ironically, and tantamount to its biodiversity, Mexico has one of the highest deforestation rates worldwide (Challenger \& Dirzo 2009). In particular, the State of Michoacán, where the main part of this study was done, lost more than 800,000 ha. of temperate and tropical forest during the 70's and 90's (Bocco et al. 2001) increasing habitat fragmentation and possibly isolation among populations. Fragmentation may reduce population sizes and consequently may affect pollen flow (Rosas et al. 2011), reproductive success and finally the viability of populations (Murren 2002, Leimu et al. 2006). Fragmentation may especially affect biotic pollinated, endemic dioecious species, and it is thus essential to assess their population sizes and sex ratios (Leo et al. 1997, Yu \& Lu 2011). A recent review on dioecious species, found that sex-ratio deviates from equality in half of the studied species being male-biased almost twice as common as female-biased (Field et al. 2013). Hypotheses that try to explain male-biased sex ratios on dioecious species, emphasize the divergent allocation to vegetative and reproductive process in males and female plants (Lloyd \& Webb 1977, Johnson et al. 2015). Accordingly, a higher reproductive allocation by females (because they need to allocate nutrients to flowers, fruits and seeds, whereas males invest only in flowers) may reduce their vegetative growth, flowering frequency and increase mortality among female plants, increasing male-biased sex ratios (Lloyd \& Webb 1977, Espírito-Santo et al. 2003). However, few empirical studies have actually measured total investment in reproduction of males and females (see Avila-Sakar \& Romanow 2012, Johnson et al. 2015). In addition, the existence of gender dimorphism in floral traits related to pollinator attraction such as flower size and number of flowers are predicted to evolve through selection on male function rather than on female function in accordance to Bateman's principle. Therefore, on dioecious species with biotic pollination we expect more and larger flowers on male plants than on female plants (Delph 1996, Vaughton \& Ramsey 1998). In extreme cases of floral dimorphism, pollinators may show strong preferences for one sex (usually males), which could even place showy dioecious species at a higher risk of extinction (Vamosi \& Otto 2002). In order to estimate the viability of natural populations of the Mexican endemic dioecious animal-pollinated shrub Fuchsia parviflora we estimated their population sizes and sex ratios and evaluated the dimorphism in primary and secondary sexual characters. Specifically, we have the following predictions: 1) Stochasticity in sex ratio will be higher in small populations where a male or female-biased may occur. 2) A positive relationship between population size and number of flowers and fruit production is expected 3) Male individuals will have both, larger floral traits and number of flowers than female plants, in accordance to Batema's principle.

\section{Materials and methods}

Study species and study site. Fuchsia parviflora Lindl. (Onagraceae), is an endemic dioecious, short live, scattered shrub (1.5 - 4 m height) from west-central Mexico (Figure 1) that inhabits the steep canyons and barrancas of the broad-leaved evergreen forest understory occurring between 1,500-2,500 m (Breedlove 1969). The flowers are red with four sepals and four petals forming a cylindrical hypanthium. Staminate flowers have eight stamens and are larger than pistillate flowers (see results), which have four stigmatic lobes and a developed ovary. Bumblebees and hummingbirds have been reported as pollinators (Breedlove 1969). The fruits are small berries, black when mature, dispersed by birds, and each fruit contains 10-20 seeds (Breedlove 1969). Some individuals obtained from seeds growing at the greenhouse, began to flower after one year of being planted (E. Cuevas unpublished data) and no clonal reproduction has been observed.

Sex ratio. This study was carried out during 2012 and 2013 in natural populations of F. parviflora in the states of Michoacán and Jalisco, Mexico (Figure 1). We used herbarium specimens 
from the three most important herbaria of Mexico (MEXU, IEB and ENCB) as a source of candidate locations for natural populations. We visited the candidate locations during the flowering peak (August-September), trying to cover the distributional range of the species; however, in some cases it was not possible to find the plants after exhaustive searches (i.e., Sinaloa and Estado de Mexico) and in other cases the sites were not visited for lack of security (i.e., Guerrero). Distances among populations range between 3 and $185 \mathrm{~km}$. Once we located a population, we estimated population size and sex ratio. In populations along the rivers $(1,2,3,8$ and 11), we checked both sides of the river for 1-2 km depending on the particular conditions in order to locate all identified individuals. We stop plant searching after walking $200 \mathrm{~m}$ without finding a plant. Populations in some cases were delimited by lakes (population 5) or by small villages (6 and 12). In other cases, we established two quadrats $(100 \times 100 \mathrm{~m})$ and registered all individuals inside (population 3). Operational sex ratio was estimated from reproductive individuals, by examining the morphology of two or three flowers per plant, and was estimated as: males/(males + females), so that low values of 0.5 indicate female bias and higher values of 0.5 indicate male bias. In total, we estimated sex ratio in twelve populations. Five populations were measured only once (populations 8-12) in 2012, and the rest of the populations were measured three times in 2013 (populations 1-7). We performed three censuses during the same flowering season in 2013 (July, August and September), to know whether flowering sex ratio changed along the year within each population. No differences were found among censuses in any population (chisquare test for homogeneity of proportions; in all cases $\mathrm{df}=2$ and $P>0.05$ ) and thus data from the third census was chosen for analysis, given that sample size was highest. During all censuses for populations 1-7 we also counted the number of immature individuals to have an estimate of the number of non-reproductive individuals in each population.

Gender differences in plant and floral traits. During the flowering peak (August-September) in each of the 12 populations, plant height and number of flowers was estimated in 20 individuals / gender / population except for populations 9, 10 and 12 where a lower number of individuals was found. In addition, floral tube and corolla diameter (three flowers per plant / gender) were estimated in 20 individuals per gender in the first seven populations. Floral longevity was estimated only in one population using 12 plants per gender and three flowers per plant. Each flower was tagged the day it opened and checked every day until flowers wilted. Finally, the number of fruits per plant (20 female plants / population) was estimated in November 2013 in the first seven populations.

Data analyses. Sex ratio was first analyzed for all twelve populations pooled, and then for each population independently. We performed binomial tests for all populations (pooled data) and then for each population, to determine whether sex ratio (proportion of male: female plants) was significantly different from 0.5 . We tested for differences in sex ratio among populations using a generalized linear model, assuming a binomial distribution. The relationship between population size, (log-transformed) and: a) relative male frequency, b) number of flowers per plant and c) fruit production was explored by means of linear correlations. To compare the number of flowers between genders and populations, a generalized linear mixed model was employed using gender as fixed factor and population as a random effect, assuming a Poisson distribution, and correcting for over-dispersion. Comparisons of plant height, floral tube and corolla diameter (log-transformed) between morphs were performed using linear mixed models, using plant gender as a fixed effect and population as a random effect. For the number of flowers, data from the second census (flowering peak) was used. The mean values of floral tube and corolla diameter per plant were used for the analyses. All statistical analyses were performed in R 2.9.2 (R Core Development Team).

\section{Results}

Sex ratio. The number of flowering individuals per population varied from 14 to 544, although most populations showed between 100 and 200 individuals (Figure 1) and the number of immature individuals ranged between 1 and $10 \%$ (Figure 1). Overall 1,864 flowering individuals 
Figure 1. The distribution of Fuchsia parviflora (black dots) in accordance to Breedlove (1969). The location of the 12 studied populations, the number inside or aside each pie chart indicates the population number. The size of each pie chart is proportional to the population size (i.e. population $2=544$ individuals and population $10=14$ individuals). Non-reproductive individuals are only shown in the first seven populations. An overall male-biased was found and the asterisk indicates populations where the number of male plants was significantly higher (Probability of success: P.S $)=0.72, P=$ 0.01 , for population 9 ; P.S = $0.78, P=0.05$ for population 10 ; and P.S $=0.75, P<0.001$, for population 12 .

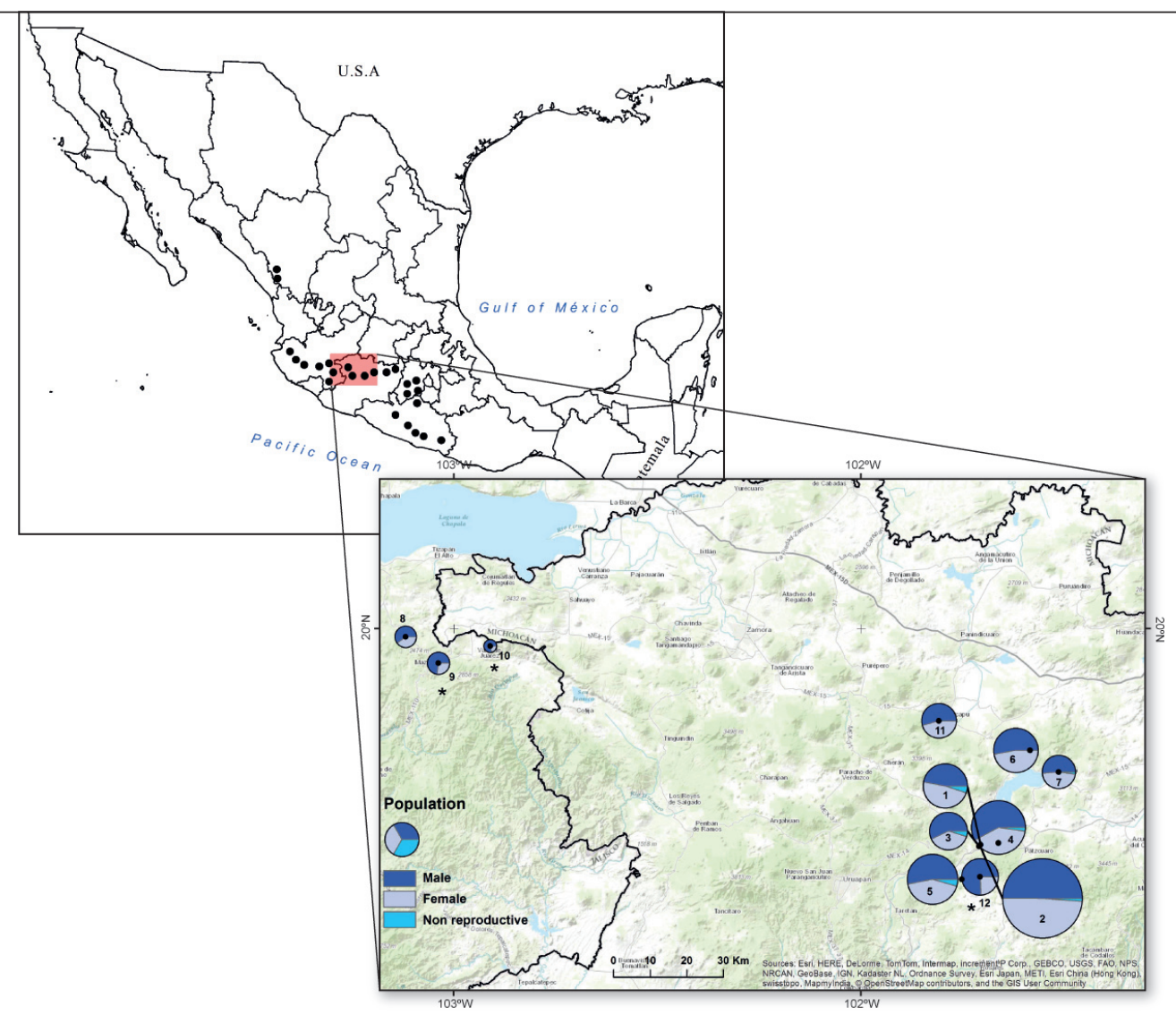

were found in the twelve populations, and the number of male plants $(1,038)$ was significantly greater than that of females ( 826 ; overall sex ratio $=0.6$, Probability of success $=0.52 ; P<0.03$; Figure 1). In three populations the number of male plants was significantly higher than that of females according to exact binomial tests, after Bonferroni correction (Figure 1). According to the GLM, sex ratio was significantly different among populations (Deviance $=63.7, \mathrm{df}=11, P$ $<0.001$ ). A negative significant correlation was found between population size and relative male frequency $\left(r^{2}=-0.45, P=0.02\right.$, Figure 2$)$, however, no relationship was found between population size and fruit production $(P=0.35$, average fruit production per plant $58 \pm 8.8)$ or population size and male $(P=0.13)$ or female $(P=0.39)$ flower display.

Gender differences in plant and floral traits. The height of mature plants $(133.14 \mathrm{~cm} \pm 2.22)$ was different among populations $\left(F_{11,1833}=23.8, P<0.0001\right)$ but did not differ between genders within populations $\left(F_{12,1833}=0.24, P=0.99\right.$; Figure $\left.3 \mathrm{~A}\right)$. The average number of flowers per plant $(20.28 \pm 0.9)$ differed among populations (Deviance $=15,304, \mathrm{df}=11, P<0.0001)$ and also the interaction between genders within population (Deviance $=1,530, \mathrm{df}=1, \mathrm{P}<0.0001$ ). In most populations, male plants produced more flowers than females (Figure 3A); however, this difference was significant only in some populations (Figure 3B). Average staminate flower longevity (3.8 days \pm 0.16$)$ did not differ from that of pistillate flowers $(3.6 \pm 0.18$; $\left.F_{1,48}=0.94, P=0.33\right)$. In the seven studied populations, staminate flowers had wider corolla diameters $\left(5\right.$ to $7.6 \mathrm{~mm}$ ) than pistillate flowers (corolla diameter 4.7 to $6.4 ; F_{6.823}=44.87, P<0.001$; Figure 3C). Staminate flowers also had consistently longer floral tubes (range 7.7 to $11.5 \mathrm{~mm}$ ), than pistillate flowers (range 3.9 to $6.1 ; F_{7.823}=118.48, P<0.001$; Figure 3D).

\section{Discussion}

Sex ratio. Recent reviews of sex ratio in dioecious species report that male-biased sex ratios are almost twice as frequent as female-biased sex ratios (Sinclair et al.2012, Field et al. 2013). 
Figure 2. A significant negative relationship between population size (log-transformed) and male frequency for the 12 studied populations of Fuchsia parviflora.

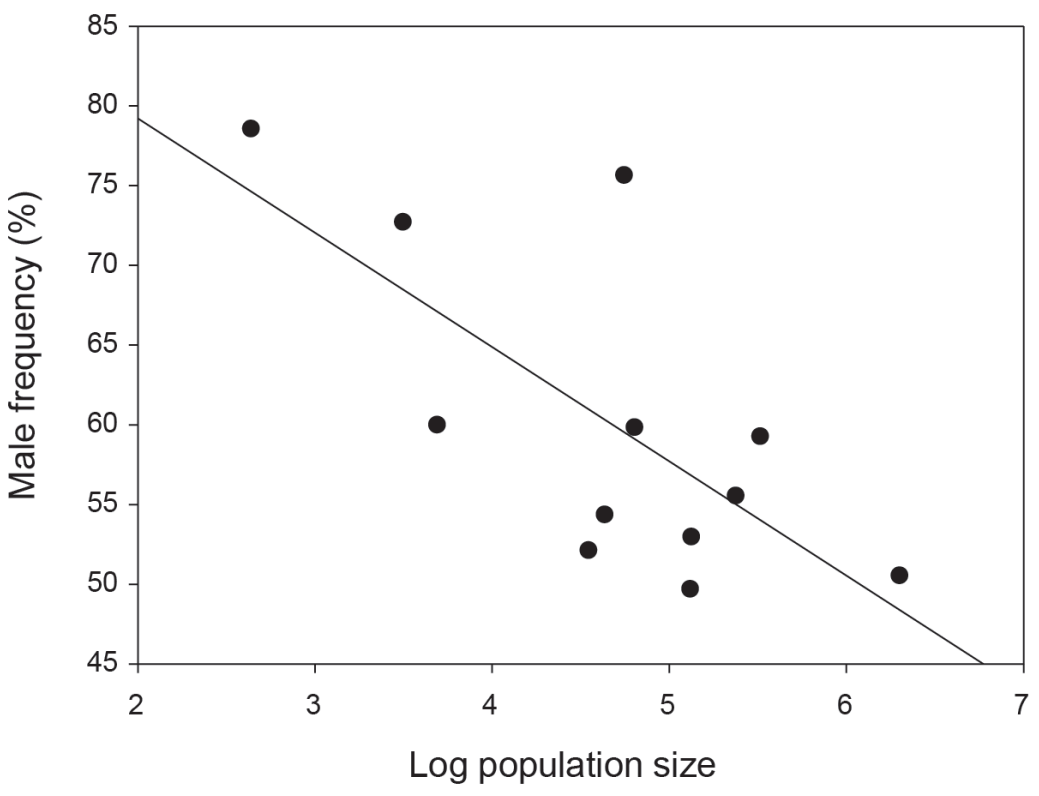

In particular, male-biased sex ratio was associated to fleshy fruits, biotic pollination and seed dispersal (Sinclair et al. 2012). Fuchsia parviflora, shows those characteristics and a significant overall male-biased sex ratio was found $(P<0.03)$. Nevertheless, only three populations had significantly more males and two of those populations had also the lowest number of flowering individuals (Figure 1). Therefore, in those cases male-bias sex ratio is probably related to population size, as the negative association between male frequency and population size suggests (Figure 2). However, if biased sex ratio was only due to stochastic events, we expect to find male and female-biased sex ratios. The fact that we only found male-biased sex ratio suggests that other factors may favor males versus female plants.

The relatively low number of immature individuals found in the studied populations (Figure 1) suggests a low recruitment of individuals or may also be the consequence of a short juvenile stage, as suggested by some individuals that began flowering during their first year of growth. The fact that sex ratio did not vary along the flowering season gives us more confidence on our sex ratio estimations. Few studies have reported the effect of population size on sex ratios (Soldaat et al. 1997, Somanathan \& Borges 2000, Yu \& Lu 2011). If most individuals in a small population are males this may reduce the chances of fruit production and therefore the viability of populations. On the contrary, male-biase could also result in abundance of pollen competition and thus greater genetic quality of offspring, lower probability of fruit and seed abortion and therefore greater fruit production in the available females, as suggested by the relatively high fruit production found on the evaluated populations (1-7). Unfortunately, we could not estimate fruit production in some of the smaller populations. Yu \& Lu (2011) found that small populations of the dioecious Pistacia chinensis had a male-biased sex ratio, compared with larger, nonfragmented populations. They found that male-biased populations were established in soils with low nitrogen availability and they concluded that fragmentation affects soil nitrogen conditions at the microhabitat scale. We did not measure micro-environmental conditions in our populations, but further investigation on aspects such as soil nitrogen and water content could clarify whether they are relevant in determining sex ratio in $F$. parviflora. Data of sex ratios from seeds planted in a common garden from five natural populations of $F$. parviflora, showed no evidence of biased sex ratio at flowering, suggesting that abiotic factors, such as soil nutrients or biotic interactors as herbivores (Avila-Sakar \& Romanow 2012) may affect male and female plants differently.

Flower number may have important consequences for pollinator attraction (Barrett \& Hough 2013). In Fuchsia parviflora, flower number in males was barely higher than that of female plants in most populations evaluated, even though floral longevity did not differ between genders. This result is in accordance with other studies in animal-pollinated dioecious plants (Delph 

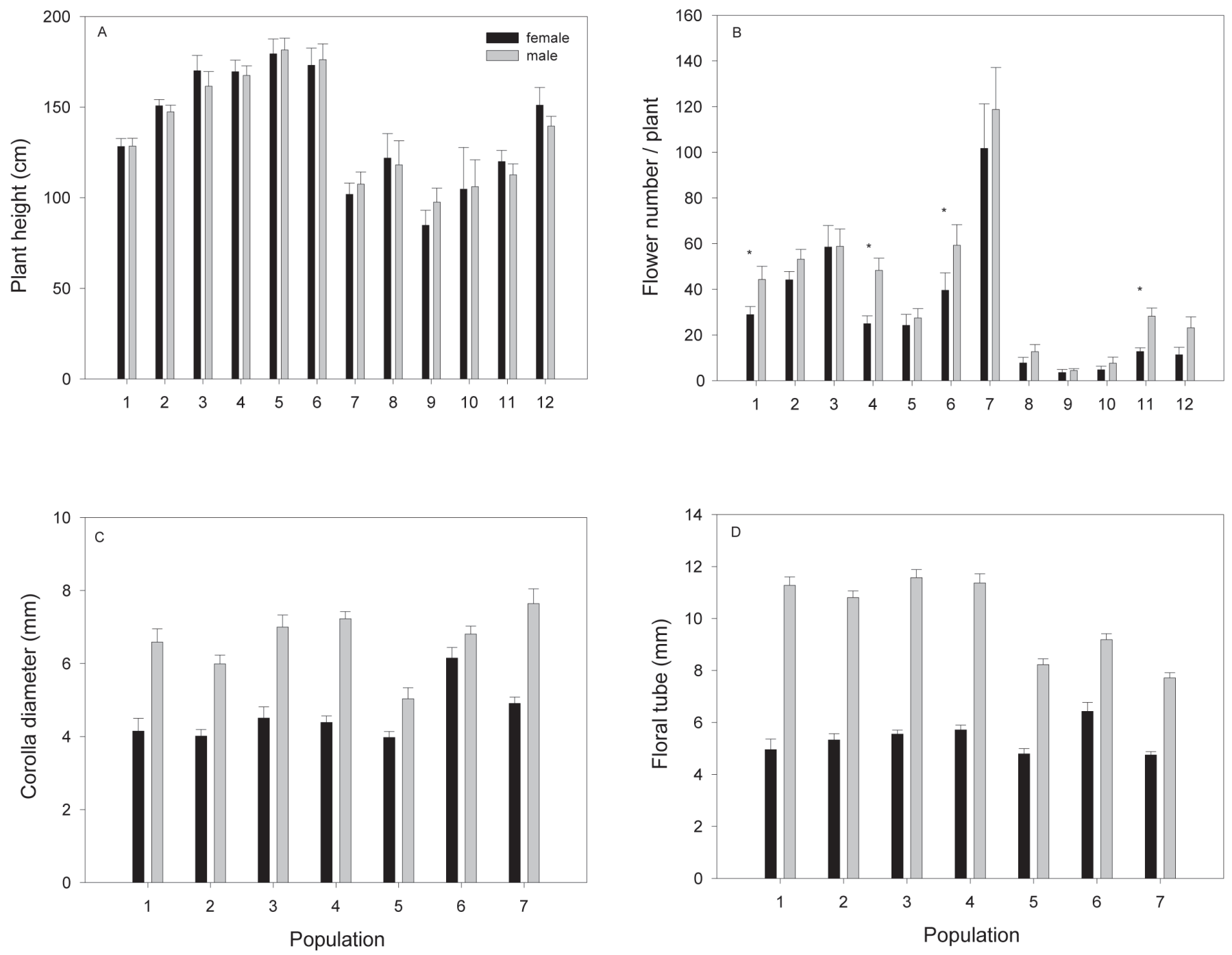

Figure 3. Means ( $\pm 1 \mathrm{SE}$ ) for plant characters and floral traits by population and gender in Fuchsia parviflora. A) Plant height. B) Flower display, the asterisk shows populations where males had significantly more flowers than female plants, $(P<0.05)$. In population two, the difference was near significance $(P=0.06)$. C) Corolla diameter. D) Average floral tubes length. In all populations staminate flowers had wider corollas diameter and longer floral tubes than pistillate flowers $(P<0.001$, for all populations).

et al. 2005); however, the higher number of flowers in males was only significant in three populations (Figure 3B). In other species, male plants produced many times more flowers than female plants (Bond \& Maze 1999, Delph et al. 2002). Consistently with the study by Delph et al. (1996), staminate flowers were significantly longer and wider in all evaluated populations. The same pattern has been found in other dimorphic species of Fuchsia where pistillate flowers are smaller (Godley 1955 in F. excorticata and F. perscande, Arroyo \& Raven 1975 in $F$. microphylla and F. thymifolia, Atsatt \& Rundel 1982 in F. lycioides, González et al. 2016. in F. obconica). The floral differences found between sexes may contribute to pollinators preferentially visiting staminate flowers and may potentially promote pollen limitation. However, so far no evidence of pollen limitation has been found in natural populations (González et al. 2016). Furthermore, no asexual seed production was found in flowers excluded from pollinators (González et al. 2016), which highlights the dependence on pollinators for seed production in this species. In addition, pistillate flowers of $F$. parviflora were preferentially visited by insects (bees and wasp) and staminate flowers by hummingbirds. However, despite these differences in preferences visits between genders, fruit production was apparently not affected (after comparing natural $v s$. pollen supplemented flowers). This visitation pattern may be a consequence of 
the differences in flower size between genders, given that nectar production and concentration did not differ between male and pistillate flowers (González et al.2016).

Dioecious species with biotic pollination are particularly sensitive to stochastic events which may increase biases in sex ratios resulting in a low fruit production. Furthermore, gender differences in flower size and number may also decrease fruit production. Although some populations in this study showed a slight male biases sex ratio, male flowers were larger and in some populations male floral display was higher, fruit production seem not to be affected on the evaluated populations.

\section{Acknowledgements}

The authors thank V. Robledo, M. Díaz, R.L. Hidalgo and A. López for field assistance and G. Cuevas for her help with the maps. González C. and Avila- Sakar G. reviewed earlier versions of this manuscript. This work was supported by a research grant from Consejo Nacional de Ciencia y Tecnología (CONACyT grant no. 105952) to the first author and from the Universidad Michoacana de San Nicolás de Hidalgo. This work was written during a sabbatical stay of the first author supported by CONACyT.

\section{Literature cited}

Arroyo MTK, Raven PH. 1975. Evolution of subdioecy in morphologically gynodioecious species of Fuchsia sect Encliandra (Onagraceae). Evolution 29: 500-511. DOI: 10.2307/2407262

Atsatt PR, Rundel PW. 1982. Pollinator maintenance vs. fruit production: partitioned reproductive effort in subdioecious Fuchsia lycioides. Annals of the Missouri Botanical Garden 69: 199-208. DOI:10.2307/2398790

Avila-Sakar G, Romanow CA. 2012. Divergence in defence against herbivores between males and females of dioecious plant species. International Journal of Evolutionary Biology. DOI: $10.1155 / 2012 / 897157$

Barrett SCH. 2010. Understanding plant reproductive diversity. Philosophical Transactions of The Royal Society B. 365: 99-109. DOI: 10.1098/rstb.2009.0199

Barrett SCH, Hough J. 2013. Sexual dimorphism in flowering plants. Journal of Experimental Botany 64: 67-82. DOI: $10.1093 / \mathrm{jxb} / \mathrm{ers} 308$

Bocco G, Mendoza M, Masera OR. 2001. La dinámica del cambio del uso del suelo en Michoacán. Una propuesta metodológica para el estudio de los procesos de deforestación. Investigaciones Geográficas, Boletin del Instituto de Geografía, UNAM 44: 18-38.

Bond WJ, Maze KE. 1999. Survival cost and reproductive benefits of floral display in a sexually dimorphic dioecious shrub, Leucadendron xanthoconus. Evolutionary Ecology 13: 1-18. DOI: 10.1023/ A: 1006581412580

Breedlove, DE. 1969. The systematics of Fuchsia section Encliandra (Onagraceae). University of California Publications in Botany Vol. 53. Berkeley and Los Angeles: University California Press.

Challenger A, Dirzo R. 2009. Factores de cambio y estado de la biodiversidad. In: March IJ, comps. Capital Natural de México, Volumen II: Estado de conservación y tendencias de cambio. México DF: Comisión Nacional para el Conocimiento y Uso de la Biodiversidad.

Delph LF, Galloway LF, Stanton ML. 1996. Sexual dimorphism in flower size. The American Naturalist 148: 299-320. DOI: $10.1086 / 285926$

Delph LF, Knapczyk FN, Taylor DR. 2002. Among-population variation and correlation in sexually dimorphic traits of Silene latifolia. Journal of Evolutionary Biology 15: 1011-1020. DOI: 10.1046/j.14209101.2002.00467.x

Delph LF, Gehring JL, Arntz AM, Levri M, Frey FM. 2005. Genetic correlations with floral display lead to sexual dimorphism in the cost of reproduction. The American Naturalist 166: S31-S41. DOI: $10.1086 / 444597$

Espírito-Santo MM, Madeira BG, Neves FS, Faria M, Fagundes M, Fernandes GW. 2003. Sexual differences in reproductive phenology and their consequences for the demography of Baccharis dracunculifolia (Asteraceae), a dioecious tropical shrub. Annals of Botany 91: 13-19. DOI:10.1093/aob/ $\operatorname{mcg} 001$

Field DL, Pickup M, Barrett SCH. 2013. Comparative analyses of sex-ratio variation in dioecious flowering plants. Evolution 67: 661-672. DOI: 10.1111/evo.12001

Godley EJ. 1955. Breeding systems in New Zealand Plants I. Fuchsia. Annals of Botany 76: 549-559. DOI:10.1093/oxfordjournals.aob.a083446 
Received:

October 4th, 2016

Accepted:

January 18th, 2017
González C, Álvarez-Baños A, Cuevas E. 2016. Floral biology and pollination mechanism of four Mexico-endemic Fuchsia species with contrasting reproductive systems. Journal of Plant Ecology rtw118. DOI:10.1093/jpe/rtw118.

Helibuth JC. 2000. Lower species richness in dioecious clades. The American Naturalist 156: 221-241. DOI: $10.1086 / 303389$

Johnson MTJ, Campbell SA, Barrett SCH. 2015. Evolutionary interactions between plant reproduction and defense against herbivores. Annual Review of Ecology, Evolution and Systematics 46: 191-213. DOI: 10.1146/annurev-ecolsys-112414-054215

Leimu R, Mutikainen P, Koricheva J, Fischer M. 2006. How general are positive relationships between plant population size, fitness and genetic variation? Journal of Ecology 94: 942-952. DOI:10.1111/ j.1365-2745.2006.01150.x

Lloyd DG, Webb CJ. 1997. Secondary sex characters in plants. The Botanical Review 43: 177-216. DOI:10.1007/BF02860717

González-Medrano F. 2003. Las comunidades vegetales de México. México DF: Secretaria de Medio Ambiente y Recursos Naturales.

Murren CJ. 2002. Effects of habitat fragmentation on pollination: pollinators, pollinia viability and reproductive success. Journal of Ecology 90: 100-107. DOI: 10.1046/j.0022-0477.2001.00638.x

Rosas F, Quesada M, Lobo JA, SorkVL. 2011. Effects of habitat fragmentation on pollen flow and genetic diversity of the endangered tropical tree Swietenia humilis (Meliaceae). Biological Conservation 144: 3082-3088. DOI: 10.1016/j.biocon.2011.10.003

Sinclair J, Emlen PJ, Freeman DC. 2012. Biased sex ratios in plants: theory and trends. The Botanical Review 78: 63-86. DOI: 10.1007/s12229-011-9065-0

Soldaat L, Vetter B, Klotz S. 1997. Sex ratio in populations of Silene otites in relation to vegetation cover, population size and fungal infection. Journal of Vegetation Science 8: 697-702. DOI:10.2307/3237374

Somanathan H, Borges RM. 2000. Influence of exploitation on population structure, spatial distribution and reproductive success of dioecious species in a fragmented cloud forest in India. Biological Conservation 94: 243-256. DOI: 10.1016/S0006-3207(99)00170-6

Vamosi JC, Otto SP. 2002. When looks can kill: the evolution of sexually dimorphic floral display and the extinction of dioecious plants. Proceedings of the Royal Society B 269: 1187-1194. DOI: 10.1098/ rspb.2002.2004

Vaughton G, Ramsey M. 1998. Floral display, pollinator visitation and reproductive success in the dioecious perennial herb Wurmbea dioica (Liliaceae). Oecologia 115: 93-101. DOI:10.1007/s004420050495

Yu L, Lu J. 2011. Does landscape fragmentation influence sex ratio of dioecious plants? A case study of Pistacia chinensis in the Thousand-Island lake region of China. PLos ONE 6: e22903. DOI:10.1371/ journal.pone.0022903 